DOI 10.14746/ssp.2017.2.2

\author{
Ryszard SKarzyŃSKi, Elżbieta KuŻELEWSKA
}

Uniwersytet w Białymstoku

\title{
Bezpieczeństwo jako zjawisko społeczne
}

Streszczenie: Bezpieczeństwo słusznie zostało w Polsce zaliczone do nauk społecznych. Carl von Clausewitza głosił, że wojna jest kontynuacją polityki innymi środkami. Według Clausewitza, wojna jest „aktem stosunków pomiędzy ludźmi”, czyli jest zjawiskiem życia społecznego. Clausewitz nie tylko wyjaśnił fenomen walki i wojny, ale także ich genezę przez pryzmat funkcjonowania społeczeństwa i kwestii bezpieczeństwa - nie jako stanu braku zagrożeń, ale takiego reagowania na zagrożenia. Celem artykułu jest ukazanie bezpieczeństwa jako zjawiska społecznego poprzez rozróżnienie pomiędzy bezpieczeństwem i przetrwaniem. Trafnie Hobbes twierdził, iż zapewnienie bezpieczeństwa społeczeństwu funkcjonującemu w formie zbiorowości (czyli poza państwem) nie jest możliwe, ponieważ nad jego egzystencją nikt nie czuwa. Oznacza to, że takich bytów społecznych dotyczy jedynie problem przetrwania w warunkach wewnętrznej rywalizacji małych grup, których proporcje sił łatwo i szybko się zmieniają. Problem bezpieczeństwa staje się jeszcze bardziej znaczący, gdy pojawia się ewentualność dezintegracji takiej całości, czy to od wewnątrz (np. zdrada), czy przez obcych, gdy dokonują oni penetracji związku (imigracja), albo próbują go zniszczyć w warunkach rywalizacji (agresja).

Slowa kluczowe: bezpieczeństwo, Clausewitz, społeczeństwo, konflikt

\section{Wprowadzenie}

Dezpieczeństwo zostało w Polsce zaliczone do nauk społecznych i ta Dkwalifikacja nie jest obecnie poddawana w wątpliwość. Cóż jednak znaczy takie umiejscowienie nowej dyscypliny i jakie konsekwencje z niego wynikają? Czy uświadamiamy sobie, że teza o przynależności bezpieczeństwa do nauk społecznych nie jest wcale oryginalna? Faktycznie zaś mamy tu do czynienia z ustaleniami poczynionymi bardzo dawno.

Każdy polski oficer zna twierdzenie Carla von Clausewitza, że wojna jest kontynuacją polityki innymi środkami. W traktacie $O$ wojnie Clausewitz pisze, iż wojna jest „aktem stosunków pomiędzy ludźmi”, czyli jest to „zjawisko życia społecznego" (Clausewitz, 1995, s. 115). O wojnie nie jest więc niczym innym, jak studium polityki i strategii rozumianych 
w kontekście funkcjonowania sieci interakcji społecznych. I na tym właśnie polega ponadczasowe znaczenie tego traktatu, powstałego dwa wieki temu. On stanowi ważny wkład nie tylko do wyjaśnienia fenomenów walki i wojny, ale także ich genezy, przez pryzmat funkcjonowania społeczeństwa i kwestii bezpieczeństwa, nie jako stanu braku zagrożeń, ale takiego reagowania na zagrożenia, aby utrzymać je w ryzach, a w sytuacji krańcowej, aby zwyciężyć.

Celem artykułu jest ukazanie bezpieczeństwa jako zjawiska społecznego nie z powodu jego oficjalnej kwalifikacji, która, wedle naszej wiedzy, nigdzie nie została głębiej uzasadniona. Problem bezpieczeństwa jako zjawiska społecznego często jest lekceważony, niedoceniany. Brakuje głębszej refleksji, jakie z tego faktu wynikają konsekwencje. Należałoby rozróżnić pomiędzy bezpieczeństwem i przetrwaniem, jak to pokazał już kilkaset lat temu w swoich rozważaniach socjologicznych Tomasz Hobbes (Hobbes, 1954, s. 147-152). Zapewnienie bezpieczeństwa społeczeństwu funkcjonującemu w formie zbiorowości (czyli poza państwem, w warunkach anarchii) i gatunkowi ludzkiemu nie jest możliwe, ponieważ nad ich egzystencją nikt nie czuwa, nikt się nawet do niej nie odnosi. Takich bytów społecznych dotyczy jedynie problem przetrwania w warunkach wewnętrznej rywalizacji małych grup, których proporcje sił łatwo i szybko się zmieniają: „Łączenie się razem niedużej liczby ludzi nie daje im bezpieczeństwa" (Hobbes, 1954, s. 148).

Błędem jest utożsamianie społeczeństwa i gatunku ludzkiego z państwem i mówienie o bezpieczeństwie zbiorowości, jakimi są społeczeństwo i gatunek ludzki. Zjawisko bezpieczeństwa może zaistnieć jedynie jako stan określonego podmiotu społecznego (czyli bytu zdolnego do działań zgodnych z własnymi interesami w układach sił określających jego los) i tylko w efekcie dążenia do jego zapewnienia w ramach złożonych struktur organizacyjnych. W konsekwencji problem bezpieczeństwa odnosi się wyłącznie do związku społecznego wyposażonego w strukturę i władzę, ponieważ jedynie ona jest w stanie zabiegać o ograniczenie czy neutralizację zagrożeń. W przypadku zbiorowości, jakimi są społeczeństwo i gatunek ludzki, taka zdolność nie występuje. Człowiek jest częścią zbiorowości. Spełnia cele i funkcje nie zawsze przystające do jego celów indywidualnych.

Mówiąc prościej: społeczeństwo w sprzyjających warunkach może samo przetrwać jako zbiorowość, ale o jego bezpieczeństwie mówimy tylko wtedy, gdy zapewnia mu je państwo. Dlatego powinno się mówić o bezpieczeństwie państwa, co oznacza określony stan tegoż państwa 
jako podmiotu (w stosunkach wewnętrznych i zewnętrznych), czyli jego specyficznej struktury organizacyjnej i zamieszkującego go społeczeństwa. Natomiast w przypadku gatunku ludzkiego występuje jedynie szansa przetrwania, nie istnieje bowiem struktura organizacyjna zapewniająca mu bezpieczeństwo. Tym samym nie można mówić o bezpieczeństwie gatunku ludzkiego. Kiedy natomiast mówimy o bezpieczeństwie społecznym, mamy na myśli bezpieczeństwo społeczeństwa żyjącego w państwie, a nie społeczeństwa dowolnego, na przykład w stanie anarchii.

Podstawowe rozróżnienie socjologiczne, niezbędne do zrozumienia zjawisk społecznych, czyli rozróżnienia pomiędzy całościami społecznymi i zbiorowościami ludzkimi, jest warunkiem wyjaśnienia problemów wynikających z kształtowania się i funkcjonowania organizacji ludzkich i systemów społecznych. Jednym z tych problemów jest bezpieczeństwo. Oczywiście rozumiane nie potocznie, tylko naukowo, a więc jako zjawisko społeczne wynikające ze sposobu istnienia gatunku ludzkiego.

Myślenie w kategoriach zbiorowości i całości społecznych, organizacji i systemów społecznych, powoli staje się standardem teorii społeczeństwa, czyli teorii stawiającej sobie za cel wyjaśnianie zjawisk społecznych. Można je uznać za fundament nowoczesnej socjologii, ponieważ pozwalają zrozumieć wiele podstawowych fenomenów społecznych (Ossowski, 1983, s. 72-79; Sztompka, 2002, s. 179-198), w tym także z zakresu socjologii zjawisk politycznych i socjologii stosunków międzynarodowych (Skarzyński, 2006, s. 83-102). Warto bliżej przeanalizować tę kwestię, ze względu na jej znaczenie dla zrozumienia problemu bezpieczeństwa, która pozwala wyjaśnić przyczyny przynależności bezpieczeństwa do nauk społecznych. Lepiej uzmysłowi nam też, że bezpieczeństwo jest czymś zupełnie innym aniżeli przetrwanie.

W tym tekście chcielibyśmy nawiązać do Clausewitza i rozwinąć jego rozumienie zagrożenia, konfliktu oraz kwestii bezpieczeństwa, która przecież cały czas przewija się w traktacie $O$ wojnie. Jeśli są to zjawiska wynikające ze stosunków pomiędzy ludźmi, jak twierdził generał, przeto mają charakter społeczny, a podstaw wiedzy o nich dostarcza nam socjologia, przede wszystkim zaś socjologiczna teoria społeczeństwa ${ }^{1}$,

${ }^{1}$ Zwracamy uwagę na socjologiczną teorię społeczeństwa, ponieważ termin „teoria społeczeństwa” jest dzisiaj rozumiany tak różnie, że to dookreślenie wydaje się konieczne. Socjologiczna teoria społeczeństwa oznacza teorię dyscypliny nauki, a nie teorię marksistowską, feministyczną czy narodową. Różnica ma charakter zasadniczy, nawet jeśli obecnie wielu reprezentantów środowiska akademickiego może twierdzić, że nie istnieje teoria dyscypliny nauki. 
dysponująca usystematyzowanym zbiorem kategorii analitycznych (Poleszczuk, 2014). Spróbujmy więc głębiej przeanalizować tę kwestię, aby zbadać czy fenomen bezpieczeństwa daje się lepiej wyjaśnić na gruncie socjologii, aniżeli na gruncie innych dyscyplin nauki. Gdyby tak było, wtedy dla nauki o bezpieczeństwie istniałaby tylko jedna droga rozwoju, ta zbudowana na fundamencie socjologicznym, a tzw. „,nauki o obronności” czy „nauki wojskowe” nie miałyby tu nic do powiedzenia. Byłyby co najwyżej subdyscyplinami bezpieczeństwa, które także należy, jak wskazał Clausewitz, budować na gruncie nauki badającej stosunki społeczne, czyli socjologii.

\section{Podstawy socjologii bezpieczeństwa}

Problematyka socjologiczna nie jest obca specjalistom z zakresu bezpieczeństwa. Jednak jej ujęcia są zdecydowanie bliższe wiedzy potocznej, aniżeli naukowej (Bezpieczeństwo..., 2001; Socjologiczne..., 2001). Naukowej teorii socjologicznej obcy jest prosty opis, ponieważ za jego pomocą nie da się niczego zrozumieć, kiedy mamy do czynienia ze złożonymi zjawiskami. Opis jest prezentacją, natomiast teoria jest próbą pokazania i wyjaśnienia jak ludzie działają, zachowują się, wchodzą w interakcje, rozwijając stosunki pomiędzy sobą i organizując w specyficzne struktury (Turner, 2004, s. 1).

Dlatego podstawą prezentowanej tutaj teorii społeczeństwa jest siatka pojęciowa zbudowana na terminach elementarnych. Jej fundament tworzy Weberowskie rozumienia działania społecznego, czyli aktywności jednostki, która orientuje się na innych ludzi ${ }^{2}$. Ta jednostka, postępując w charakterystyczny dla siebie sposób wobec otaczających ją osób, wchodząc z nimi w interakcje, doprowadza do rozwijania wzajemnych stosunków. W efekcie aktywności wielu osobników następuje grupowanie się jednostek w rywalizujące pomiędzy sobą związki, czyli całości społeczne o charakterze organizacji, powiązane w system (Weber, 2002, s. 17-25).

Takie całości, w miarę postępów procesu ewolucji społeczeństw ludzkich, nie tylko stają się coraz bardziej złożone i zróżnicowane, ale także

${ }^{2}$ Weberowska teoria działania społecznego, nawet jeśli socjolodzy często nie powołują się na samego Webera, stanowi fundament współczesnej socjologii, rozumianej jako nauka wyjaśniająca zjawisko agregacji społecznej ludzi, czyli fenomen społeczeństwa (w odróżnieniu od doktryn nazywanych socjologicznymi, których celem jest projektowanie ładu społecznego). 
rywalizują pomiędzy sobą rosnącymi środkami. One mają kluczowe znaczenie dla funkcjonowania każdego z tych społeczeństw. Nie tylko jeśli chodzi o zdolność biernego przetrwania, ale także w kontekście bezpieczeństwa będącego efektem przemyślanej i coraz bardziej zaawansowanej aktywności, ponieważ owe podmioty wywierają decydujący wpływ na aktualny kształt społeczeństw, nadając działaniom ludzi sens i określając ich specyfikę.

Bezpieczeństwo nie jest więc czymś abstrakcyjnym, nie jest uczuciem (chociaż istnieją uczucia zagrożenia i bezpieczeństwa w wyniku przeżywania przez umysł położenia przenoszącego go ciała), ale kształtuje się jako fenomen w sieciach stosunków społecznych. Przeżywanie przez człowieka zagrożeń nie określa jego bezpieczeństwa, chociaż może mieć na niego wpływ, na przykład mobilizując do pewnych działań.

Dopiero faktyczne położenie człowieka w sieciach stosunków społecznych określa jego rzeczywiste bezpieczeństwo. Bezpieczeństwo to efekt zdolności reakcji na zagrożenia pojawiające się w sieciach stosunków społecznych, a także w środowisku naturalnym. Przy czym kluczowe znaczenie mają zagrożenia społeczne, ponieważ one określają także reakcje na zagrożenia przyrodnicze. Efektem tego wszystkiego jest poczucie bezpieczeństwa, które jest czymś zupełnie innym aniżeli rzeczywiste bezpieczeństwo.

Bezpieczeństwo jako problem wymaga badania i przyjęcia adekwatnych rozwiązań, mających na przykład podnieść poziom bezpieczeństwa. Bezpieczeństwo jest stanem egzystencji jednostki albo związku osobników, który nabiera znaczenia w wyniku ewolucji ludzkich zbiorowości, ponieważ stają się one coraz bardziej kompleksowe. Do tego stopnia, że istniejące $\mathrm{w}$ ich ramach związki ludzi są w stanie nie tylko prowadzić wojny, a potem wojny totalne. Te zbiorowości z czasem zaczynają dysponować środkami, które nie tylko umożliwiają im militarne zabezpieczenie się przed agresja, ale nawet konstruują i utrzymują instytucje pozawojskowego ograniczenia przemocy i agresji, czy to za pomocą traktatów, czy też specyficznych organizacji. Wszystko to, jak wskazywał Clausewitz, w efekcie funkcjonowania stosunków społecznych.

Całości społeczne wyróżniamy z racji charakterystycznych dla nich stosunków wewnętrznych, zachodzących pomiędzy ich członkami i specyficznych stosunków zewnętrznych, jakie są one w stanie utrzymywać z innymi całościami społecznymi (Skarzyński, 2006, s. 83). Byty tego rodzaju dysponują organizacją wewnętrzną i tym samym kierownictwem, ponieważ są odrębnymi związkami ludzi, mniej lub bardziej świadomych warunków swojej egzystencji (nawet jeśli ta świadomość często dostępna 
jest głównie ich elitom i przywódcom), własnych interesów, dążą do reprodukcji, a przynajmniej część z nich dysponuje nawet zdolnością walki o przetrwanie i ewentualnie planowej modyfikacji własnego położenia ${ }^{3}$. Ich dążenie do przetrwania, czy to pokojowe, czy to w walce, jest efektem działania pod kierownictwem (jego zaawansowaną formą jest przywództwo), ma charakter nie tylko mniej lub bardziej uświadomiony, ale również znajduje swój wyraz w ideach, za pomocą których takie związki chcą uzasadnić swoje istnienie, zamiary i postępowanie.

Całości społeczne są zjednoczeniami osobników o różnym typie więzi wewnętrznej i strukturze. Bogactwo, różnice i podobieństwo więzi można zrozumieć porównując na przykład państwo, ród, partię polityczną, firmę i związek przestępczy. Relacje pomiędzy ich członkami podlegają specyficznym regulacjom i reprodukcji w czasie. Ponieważ cechuje je gotowość do podejmowania świadomych, planowanych działań, muszą odnosić się do różnorakich zagrożeń, próbując je kontrolować i neutralizować, tym samym dążąc do zapewnienia sobie bezpieczeństwa, niezależnie od tego, jaka jest ich pozycja społeczna. W przeciwnym razie nie byłyby w stanie funkcjonować, podlegałyby rozpadowi i likwidacji. Rzadko takie procesy wywołuje środowisko naturalne, na przykład w efekcie działania żywiołów. Zwykle są one dziełem całości społecznych lepiej przygotowanych do rywalizacji w specyficznych warunkach.

Kluczową rolę w funkcjonowaniu całości społecznych odgrywają zagrożenia ze strony innych całości społecznych, które z nimi rywalizują o zasoby i wywierają na nie presję. Nie tylko zmuszając do uczestnictwa w walce, ale przede wszystkim do zapewnienia sobie warunków poprawiających zdolność przetrwania, czyli podnoszących poziom bezpieczeństwa. Jak pisał Kant, nie ma mowy o wiecznym pokoju tak długo, jak choćby w jednym państwie istnieje stała armia. Każda armia musi być zbrojna i wciąż prowadzone są prace nad udoskonaleniem uzbrojenia. Najtańszym zaś sposobem niszczenia przestarzałego uzbrojenia jest użycie go w wojnie. Istnienie armii stanowi zagrożenie dla pokoju (Kant, 1995), a tym samym bezpieczeństwa.

Problem bezpieczeństwa w przypadku całości społecznych nie ogranicza się do zachowania integralności wewnętrznej i obrony. Zjednocze-

3 Przez co należy rozumieć nie podniesienie poziomu życia ich członków (była to zawsze kwestia drugorzędna, aż do czasu powstania kapitalizmu - w tym systemie ludzie kierują się interesem sprzedaży i zysku, przez co podnosi poziom życia ludzi), ale przede wszystkim zdolności oddziaływania na inne całości społeczne poprzez zmianę pozycji w układach sił regulujących ich wzajemne relacje. 
nia ludzkie działają w środowisku innych bytów społecznych, w relacjach z którymi muszą zadbać także o dostęp do środków niezbędnych do ich funkcjonowania. Zwykle, kiedy tych środków brak, trzeba uczestniczyć w rywalizacji o nie, nierzadko ostrej, bezwzględnej i brutalnej. Każda całość społeczna staje się więc przedmiotem działań innych związków ludzi i musi się do nich odnosić, dostosowując własne postępowanie, a przede wszystkim struktury organizacyjne, które umożliwiają odnalezienie się w danym otoczeniu. Struktury organizacyjne pozwalają zmobilizować adekwatne środki i użyć ich w rywalizacji z innymi.

Problem bezpieczeństwa staje się jeszcze bardziej znaczący, gdy pojawia się ewentualność dezintegracji takiej całości, czy to od wewnątrz, ze strony własnych członków (zdrada), czy przez obcych, gdy dokonują oni penetracji związku (imigracja), albo po prostu próbują go zniszczyć w warunkach rywalizacji (agresja). Nie może być mowy o zapewnieniu całości społecznej bezpieczeństwa, jeśli podlega ona dezintegracji wewnętrznej. Wówczas traci zdolność reagowania na zagrożenia.

Całości społeczne działają w szczególnych warunkach, w wyniku czego podlegają selekcji. Selekcja nie oznacza tutaj eliminowania konkretnych podmiotów (aczkolwiek takie zjawisko ma miejsce cały czas), ale pewnych ich typów i zastępowania przez inne, bardziej odpowiadające wymaganiom środowiska naturalnego, przede wszystkim zaś społecznego. Eliminowanie może polegać na fizycznej likwidacji konkretnego typu całości społecznej, często jednak najpierw prowadzi do usuwania go z układów sił o większym znaczeniu do układów sił mniejszej rangi. Jak to miało miejsce na przykład w przypadku związków religijnych, tracących wpływy na rzecz innych. Proces ten wyjątkowo łatwo można zaobserwować studiując historię pierwszych teokracji zastąpionych przez władzę wielkich rodów, potem stopniowo wypieranych przez partie polityczne. Doprowadził on najpierw do wyeliminowania państw teokratycznych, a potem dynastycznych, zastapionych przez demokracje wielopartyjne.

Do całości społecznych należą takie byty społeczne, jak rodzina, ród (w tym szczególna jego forma: dynastia), sekta, kościół, firma, gang, mafia, partia polityczna czy przede wszystkim państwo. Często istnieją one w ścisłej zależności od siebie i wzajemnie się przenikają, a przede wszystkim zaciekle ze sobą rywalizują.

Państwo ma szczególne znaczenie, ponieważ gatunek ludzki jest zbiorowością podzieloną na tego rodzaju całości o charakterze terytorialnym, grupujące odrębne populacje. Każda z wymienionych wyżej całości społecznych uczestniczy w innego rodzaju rywalizacji, w odmiennych 
układach sił, ale żaden z powyższych związków nie jest w stanie się od niej uwolnić i tym samym zawsze zmaga się z zagrożeniami własnego bezpieczeństwa, które próbuje sobie zapewnić zarówno doraźnymi, jak i planowanymi działaniami.

Problem bezpieczeństwa wynika więc już ze struktury społecznej charakterystycznej dla gatunku ludzkiego, czyli ze sposobu egzystencji ludzi, którzy nie funkcjonują razem jako wspólnota gatunkowa, ale zawsze dzielą się na ugrupowania skazane na bezwzględną rywalizację, nawet jeśli często zastępuje ją współpraca. Ona dotyczy ograniczonej liczby osobników i ich związków, zawsze pociagając za sobą rywalizację z innymi, a tym samym stwarza zagrożenia, które wymagają opanowania. Także w warunkach współpracy owe całości społeczne stoją wobec problemu jej zakończenia i przejścia do fazy rywalizacji, która może nawet często przebiegać w formie walki fizycznej. Odrębne zjednoczenia osobników faktycznie generują wobec siebie wzajemnie zagrożenia nawet w fazie kooperacji.

Zbiorowości społeczne mają zupełnie inny charakter, ponieważ są tworzone przez pewną liczbę ludzi, gdy ich kontakty odznaczają się kompletnym zatomizowaniem interakcji. Nie dysponują oni w ogóle poczuciem swojej odrębności, specyficznych interesów, albo dysponują ich świadomością w bardzo niskim stopniu i nie są zorganizowani do działań mających na celu obronę własnej egzystencji oraz wspólnych dążeń (Skarzyński, 2006, s. 86-87). Tutaj mamy do czynienia jedynie z próbami przetrwania (albo indywidualnego, albo części osób, zwykle w postaci niewielkiego związku), ale nie pojawiają się działania polegające na zapewnieniu bezpieczeństwa zbiorowości jako takiej. Nie istnieje mechanizm, który by je wytworzył.

W społeczeństwach ludzkich występuje niezliczona liczba zbiorowości: kierowców, rolników, rzemieślników, mundurowych, księgowych, bankierów czy też duchownych. Oni mogą wprawdzie tworzyć i tworzą organizacje skupiające część z nich, ale specyfika ich egzystencji polega na tym, że nie istnieje organizacja łącząca wszystkich (tak, jak nie istnieje organizacja łącząca telewidzów czy podatników, chociaż może istnieć związek głoszący, że reprezentuje ich interesy). Zwykle członkowie zbiorowości przynależą do wielu różnych organizacji, jak duchowni czy, paradoksalnie, nawet ludzie poczuwający się do tożsamości narodowej.

Efektem sposobu funkcjonowania zbiorowości jest brak zdolności do zapewnienia sobie bezpieczeństwa. Ona może jedynie przetrwać w sensie statystycznym, czyli jako pewna liczba ludzi. Dlatego gatunek ludzki, 
który jest zbiorowością, nie tworzy społeczeństwa, określamy go natomiast jako populację. Warto zauważyć, że każde społeczeństwo, chociaż jest podzielone, cechuje się pewną jednością, a tej w przypadku gatunku ludzkiego nie można się doszukać. Tutaj mamy do czynienia tylko z cechami gatunkowymi i statystyką typową dla populacji. W ramach gatunku ludzkiego zawsze wyłaniają się całości społeczne, w efekcie czego rywalizacja ludzi podlega intensyfikacji.

Zbiorowości nie mają stosunków wewnętrznych i tym samym nie utrzymują stosunków zewnętrznych. Dlatego problem bezpieczeństwa dotyka indywidualnie członków zbiorowości, ale nie istnieje problem bezpieczeństwa zbiorowości, chyba że ogłosi go jakaś całość społeczna (np. zainicjuje akt ludobójstwa wobec tej zbiorowości). Ludzie przynależni do zbiorowości moga próbować wpływać na swój los i podnieść szanse przetrwania. Jednak nie dokonają tego jako zbiorowość. Odniosą się do zagrożeń i tym samym spróbują uporać z problemem bezpieczeństwa dopiero organizując się w jaką́ całość lub przystępując do funkcjonującej już całości. Jest to dla nich jedyna droga poddania kontroli własnego położenia i zapewnienia bezpieczeństwa.

\section{Naród: bezpieczeństwo narodowe a bezpieczeństwo państwa}

Przykładem typowej zbiorowości jest naród. Zjawisko to jest często przedmiotem refleksji potocznej, sugerującej jakoby narody były szczególnymi związkami, uniwersalnymi, trwale łączącymi ludzi i odgrywającymi wyjątkową rolę w czasach współczesnych, a nawet w historii. W poważnej monografii znajdujemy tezę, że państwo narodowe jest jedyną formą organizacji politycznej, zdolnej zabezpieczać interesy zbiorowe (Zalewski, 2013, s. 249). Nic bardziej mylnego. Takie poglądy są nie tylko fałszywe, ale także wyjątkowo naiwne.

Kwintesencją nonsensów związanych z rozumieniem narodu jest pojęcie „stosunki międzynarodowe”, które, rozumiane dosłownie, sugeruje, że narody wchodzą ze sobą w interakcje. Takie interakcje mają miejsce pomiędzy osobnikami przynależnymi do różnych narodów albo ich organizacjami. Nigdy jednak same narody nie wchodzą wzajemnie w stosunki ze sobą, ponieważ zbiorowości cechuje rozproszenie interakcji wewnętrznych i dlatego nie są one zdolne do jakichkolwiek działań wobec kogokolwiek, aż do momentu kiedy ich przedstawiciele zbudują jaką́ organizację zdolną do działania. Ona jednak nigdy nie łączy całego naro- 
du, ani nie reprezentuje interesów jego wszystkich członków. Często też nie reprezentuje interesów narodu.

Pojęcie narodu ma szczególne znaczenie dla zrozumienia bezpieczeństwa. Z tymi terminami wiążą się konkretne zjawiska społeczne, które przez uczonych nie mogą być pojmowane intuicyjnie, albo w języku współczesnych mediów. Tymczasem pojęcie narodu należy do najmniej uświadomionych, chociaż tak często używanych. Również w kontekście bezpieczeństwa narodowego, którego twórcy nie zdają sobie sprawy, że posługując się nim faktycznie mówią o bezpieczeństwie państwa (paradoksalnie niekoniecznie państwa narodowego).

Trafnie określono kiedyś naród ,wspólnotą wyobrażoną” (Anderson, 1997). Mało kto jednak zrozumiał to twierdzenie, tym bardziej zaś jego implikacje. Oznacza ono, że naród nie jest realnym związkiem, tylko przedstawieniem, ideą, a często elementem wizji, zbudowanych na gruncie specyficznych symboli, pozwalających wytwarzać zróżnicowane poczucie wspólnoty losu danej zbiorowości. W jego ramach toczy się walka pomiędzy odrębnymi związkami ludzkimi, chociażby przedsiębiorstwami, rodzinami, rodami czy partiami politycznymi, podobnie jak w innych zbiorowościach.

Do XIX w. faktycznie nikt nie mówił o narodach. Do tego czasu ludność najlepiej rozwiniętych kręgów cywilizacyjnych żyła w społeczeństwach dynastycznych, w których grupowała się wokół rodów i kierujących nimi (albo publicznie sprawiających wrażenie, że kierują) konsekrowanych władców. Ci przywódcy najpotężniejszych rodów ${ }^{4}$, tworzących dynastie, zwykle traktowali poddane sobie społeczeństwa jako własność z woli jakiejś siły nadnaturalnej, uznawanej za stwórcę świata i nazywanej Bogiem (której inni, zwykle wrogowie, odmawiali tych cech, przeświadczeni, że tylko ich Bóg jest prawdziwy i tylko oni mają prawo do panowania nad światem).

Świadomość narodowa zaczęła się rodzić dopiero w okresie upadku organizacji dynastycznej, niezdolnej sprostać aktualnym wyzwaniom, w szczególności nieprzygotowanej do rozwiązania problemu ambicji emancypacyjnych kolejnych grup społecznych, cofających zgodę na uznawanie siebie za własność króla czy księcia. Wtedy pojawiła się, zbudowana na wyobrażeniu abstrakcyjnej wspólnoty losu konkretnych zbiorowości, ideologia narodowa (w wielu wariantach, od umiarkowanych aż

${ }^{4}$ Dysponujących środkami, czyli przede wszystkim gospodarką pozwalającą wystawić armię do walki, aby zdobywać i utrzymać terytorium zamieszkujące przez jak największą populację, którą poddawano bezlitosnej eksploatacji. 
po nacjonalistyczne), która odcisnęła wielkie piętno na myśleniu współczesnych ludzi, w tym także na tym, co nazywa się nauką, a co faktycznie przeważnie było i jest pseudonauką.

Efekty powyższych procesów znajdujemy w wielu mitach odnoszących się do tego, czym jest naród, a przede wszystkim wskazujących na czym polega jego misja. Niektóre z nich głosiły konieczność koegzystencji i współpracy narodów, inne propagowały wizje narodu panów. Produktem tego procesu jest także żywa dzisiaj wizja „Wspólnoty Narodów" odpowiedzialnych za porządek świata. Obecnie słyszymy o niej w mediach zawsze wtedy, gdy Stany Zjednoczone podejmują interwencję w jakiejś części świata. Jak Waszyngton podaje do publicznej wiadomości, nie robi tego nigdy we własnym interesie. Zawsze posyła swoje siły specjalne albo armię w interesie (i możliwie jak najczęściej za zgoda) „Wspólnoty Narodów”.

Ta rzekoma wspólnota (która nigdy nie istniała - jedynie przedstawiciele nielicznych, aczkolwiek najpotężniejszych zbiorowości, przypisujących sobie status narodowy, spotykali się na konferencjach pokojowych kończących coraz bardziej krwawe wojny, by potem utworzyć permanentną konferencję pokojową, zwaną Ligą Narodów, a następnie Organizacją Narodów Zjednoczonych), wedle waszyngtońskiego przedstawienia, powszechna, czy też nieomal powszechna, stała się współcześnie ostatecznym punktem odniesienia globalnej polityki Zachodu. Wspólnotę pomyślano i prezentuje się jako układ współistniejących, a nawet kooperujących narodów. Jednocześnie ta wizja miała motywować do działania wobec opierających się jej uznaniu, sprzeciwiających się woli rządów wprowadzających ją państw. Także do zabijania obcych i ludobójstwa, jakie współcześnie ma miejsce między innymi na Bliskim Wschodzie.

Najnowszym produktem z gatunku wizjonerstwa, wydaje się być kontrwizja Kalifatu zbudowanego na prawie szariatu. Nie ma ona nic wspólnego z wyobrażeniem narodu. Jej inspiracją jest tradycja islamu w jej radykalnej wersji.

Efektem obu wizji, „Wspólnoty Narodów” i „Kalifatu”, jest terroryzm islamski ${ }^{5}$. Warto zauważyć, że obraz kalifatu z wizją narodową nie ma nic wspólnego, ale jest dramatycznym zagrożeniem dla bezpieczeństwa ze strony sił swoją tożsamość czerpiących z wcześniej istniejącej wizji religijnej.

5 Te zjawiska bardzo dobrze pokazują zjawisko bezpieczeństwa jako proces przebiegający w ramach systemów społecznych. 
Mity narodowe, wraz z budowanymi na ich gruncie wizjami porządku narodowego (nieistniejącej wspólnoty narodów) odgrywają ogromną rolę w XXI w. Tymczasem dostępna wiedza historyczna i socjologiczna wskazuje, że nie występował i nie istnieje naród, który w całości żył lub żyje w państwie. Naród nie organizuje się jako całość i zawsze pozostaje zbiorowością (głównie kulturową i na dodatek zróżnicowana), w obrębie której kształtują się i wyłaniają struktury organizacyjne pozwalające przeobrazić go w efekcie mobilizacji politycznej w państwo (Skarzyński, 2011, s. 231-246). Dowodzi tego niezliczona literatura przedmiotu (Mączak, 1986; Kennedy, 1994; Spruyt, 1994; Creveld, 1999; Reinhard, 2000; Schulze, 2012), której istnienia dziwnym trafem nie przyjmuje się do wiadomości w efekcie presji wywieranej na świadomość ludzi ze strony wizji narodowej.

W państwie żyje tylko część narodu, nawet jeśli jest ona przeważająca lub dominująca. W tym samym państwie żyją także inne zbiorowości narodowe, które tworzą mniejszości. Narody żyją w rozmaitych państwach, a państwo zwykle na zewnątrz reprezentuje interesy nie tylko narodu dominującego w nim, ale całego społeczeństwa, które to państwo zamieszkuje. Zwykle zresztą bardziej reprezentuje interesy jego oligarchii, która powstaje w każdym systemie ekonomicznym i politycznym, a najbardziej wyraźna jest w Rosji i na Ukrainie.

Istniały (Rzymianie) i istnieją (Kurdowie) zbiorowości o cechach przypisywanych narodom, których nie wpisuje się do historii narodów, za narody nie uznaje i nie dopuszcza do rzekomo istniejącej wspólnoty narodów. Wszystko to ma miejsce dlatego, że naród jest zjawiskiem o wiele bardziej złożonym, aniżeli prezentują to mity i wizje narodowe. Wiedza zgromadzona z kolei przez nauki społeczne o narodach jest groźna dla trwałości tychże mitów i wizji. Stąd też często jest ignorowana - także na uniwersytetach.

Każde społeczeństwo jest mieszanką etniczną. Jest nią nawet społeczeństwo japońskie, chociaż pewnie można je scharakteryzować jako najbardziej jednorodny naród świata. Jego przeciwieństwem są „Kiwi” (jak się sami coraz chętniej nazywają), czyli Nowozelandczycy. Nie są w jakimkolwiek stopniu narodem, ale przecież tworzą związek zdolny zachować integralność wewnętrzną i bronić własnych interesów. Nawet jeśli rdzenni mieszkańcy w nim zupełnie się nie liczą, zdominowani i poddani przedstawicielom innych narodów. Nowozelandczycy zostali włączeni do globalnej Wspólnoty Narodów, ponieważ taki był interes polityczny. Nieliczni Maorysi zintegrowali się z nimi, większość pole- 
gła albo wylądowała na marginesie społeczeństwa, które się wyłoniło na wyspach.

Dla zrozumienia problemu bezpieczeństwa rozróżnienie pomiędzy narodem i państwem ma kluczowe znaczenie, ponieważ naród jest zbiorowością, podczas gdy państwo jest całością społeczną. Naród nie jest więc w stanie zapewnić sobie bezpieczeństwa. Za jego bezpieczeństwo w typowych warunkach odpowiada państwo, które jako system instytucji dysponuje w tym celu powołanym aparatem, czerpie $\mathrm{z}$ wizji narodowej swoją tożsamość i podtrzymuje ją jako ideologiczny fundament własnej egzystencji. Naród istnieje tutaj tylko jako wyobrażenie i tylko w tej mitycznej roli jest potrzebny. Dzieje się tak, ponieważ państwo skupiające w sobie miliony obcych genetycznie osobników nie może istnieć bez odpowiedniej symboliki.

Symbolika może być zresztą dowolna, ważne jest tylko, aby stymulowała wyobraźnię i poruszała uczucia ludzi. Gdy nie istniała zdolna utrwalić się w ludzkich umysłach symbolika Nowozelandczyka, próżnia została wypełniona przez symbol „Kiwi”. Niezwykły, rzadki ptak, a właściwie wyobrażenie jego kształtu (ptak prowadzi życie nocne, jest płochliwy i trudno go zobaczyć) porusza uczucia miejscowych i pełni rolę znaku integrującego ludzi przybyłych z całego świata. Do tego stopnia, że coraz więcej Nowozelandczyków, zwykle tych już urodzonych na wyspach, mówi o osobie „I'm Kiwi”.

Gdy w Europie wraz z dynastiami upadła tradycyjna symbolika monarchii, zastapiła ją symbolika narodowa, która wyszła zwycięsko z rywalizacji z symboliką rasową i klasową, a także z radykalnym wariantem symboliki narodowej, czyli z nacjonalizmem. Państwo dynastyczne zostało zastapione, po przelotnej przygodzie z państwami faszystowskimi i komunistycznymi (zbudowanymi na symbolice rasowej i klasowej), przez państwo narodowe. Mamy tu do czynienia z typowymi zjawiskami politycznymi, ugruntowanymi procesami kulturowymi. Dlatego wiedza z zakresu symboliki narodowej, przedstawiana za pomocą doktryn i ideologii, nie może służyć jako podstawa do naukowego wyjaśniania zjawisk społecznych, w tym bezpieczeństwa. Nauka nie może bazować na przedstawieniach politycznych i powinna za wszelką cenę unikać metafor.

Zagrożenia występują wszędzie. Jednak o dążeniu do zapewnienia bezpieczeństwa możemy mówić tylko tam, gdzie pojawia się systematyczne, rozłożone w czasie działanie jednostki ludzkiej albo związku jednostek ludzkich, celem poddania zagrożeń przynajmniej częściowej kontroli, aby zapewnić sobie przetrwanie, reprodukcję i ewentualnie roz- 
wój. Dlatego właśnie bezpieczeństwo jest zjawiskiem społecznym i ten fenomen jako przedmiot badań, jako dyscyplina nauki należy do nauk społecznych, zaś fundamentem wiedzy z zakresu bezpieczeństwa jest socjologia.

Wyjątkowo dobrze obrazuje to analiza ludzkich zbiorowości na przykładzie narodów. Naród nie jest w stanie uporać się z problemem bezpieczeństwa dopóki nie zostanie wyłoniona jakaś organizacja reprezentująca jego interesy. Na przykład stowarzyszenie albo partia polityczna. Najlepiej reprezentuje jego interesy organizacja państwowa. Bez niej naród jest skazany na rozproszone próby przetrwania, podejmowane przez jednostki i niewielkie grupy, tworzące lokalne struktury organizacyjne. Dlatego problem bezpieczeństwa narodu nigdy nie jest problemem samego narodu, lecz jest zadaniem organizacji państwowej, kiedy ona ten naród reprezentuje.

Historia Chin wiele uczy o tym, czym jest zbiorowość, naród, mniejszość etniczna, państwo, imperium i system państw, którym Chiny były przez znaczną część swojej dynastycznej, a nie narodowej historii. Podobnie jak historia Kanady i Stanów Zjednoczonych, które nigdy nie były i prawdopodobnie nie będą państwami narodowymi, nawet jeśli mit narodu amerykańskiego został tak dobrze wyartykułowany. Stany Zjednoczone są obecnie przedstawiane jako państwo narodowe tylko z racji pozycji zdobytej przez nie w świecie w wyniku drugiej wojny światowej, kiedy odwoływanie się do symboliki narodowej zdominowało myślenie polityków i społeczeństw Zachodu. Jest to efekt narodzin globalnej potęgi imperialnej, która rzekomo ma przewodzić Wspólnocie Narodów w utrzymaniu światowego pokoju. Nawet jeśli faktycznie ciagle prowadzi wojny, to uzasadnia się, że czyni to dla światowego pokoju i dobra ludzkości. Wyobrażenie amerykańskiego państwa narodowego jest tutaj traktowane jako ugruntowanie przeżywanego zbiorowo uczucia chwały. Jednak uczucie to dostępne jest dzisiaj już tylko mniejszości tego społeczeństwa. Czy kiedykolwiek przeżywała je większość?

W kontekście problematyki narodowej należy inaczej tłumaczyć zjawisko gatunku ludzkiego, który wprawdzie istnieje, ale jest tylko globalną zbiorowością osobników bardzo specyficznego typu. Przede wszystkim nikt nie troszczy się o gatunek ludzki, dlatego w jego przypadku nie ma możliwości zapewnienia mu bezpieczeństwa. Bezpieczeństwo zapewniają sobie tylko ludzie i ich związki. Mamy zatem do czynienia z bezpieczeństwem całości społecznej, jaką jest państwo (ewentualnie społeczeństwo), nie naród. Jeśli ktoś nie zrozumiał powyższych roz- 
ważań, albo się z nimi nie zgadza, to pouczające może być dla niego poznanie splecionych ze sobą historii sześciu „narodów”: indyjskiego, pakistańskiego, afgańskiego, nepalskiego, bangladeskiego i lankijskiego. One nigdy nie istniały w rzeczywistości. Ich historia to dzieje niezliczonej liczby państw tworzących przez stulecia mniej lub bardziej złożone systemy o charakterze poliarchii, w których kluczowa rola przypadała dynastiom. Nawet w dzisiejszym społeczeństwie lankijskim, funkcjonującym w ramach państwa określanego jako „demokracja socjalistyczna”, władzę sprawują wpływowe rodziny (Peebles, 2006, s. 5). Tak samo rządziły one i rządzą w „największej demokracji świata”, czyli w Indiach. Czyż to nie paradoks? Co więcej, uwzględnić należy także ładunek emocjonalny zawarty w słowie „Gandhi”, którego historia nie jest historią rodu, a jej najbardziej intrygującą postacią nie są ani Mahatma Gandhi, ani Jawaharial Nehru, ani Indira Gandhi. Tym kimś jest Włoszka, która stała się Sonią Gandhi.

Warto też zauważyć, że nikt nie mówi o „narodzie arabskim”, a przecież jest to jedna z najliczniejszych zbiorowości w ramach gatunku ludzkiego. Może Arabów nie uznaje się za naród dlatego, że nadal funkcjonują głównie na poziomie więzi rodzinnych i rodowych, które na Zachodzie straciły na znaczeniu? A może dlatego, że są podzieleni pomiędzy dużą liczbę państw? Status narodowy Arabów uznaje się domyślnie (na podstawie przynależności państwowej), ponieważ jakoś trzeba ich wpisać do wspólnoty narodów? Tym bardziej wówczas, kiedy wypisało się im receptę na implementację instytucji demokratycznych.

Rozważenie argumentów socjologicznych pokazuje, że termin „bezpieczeństwo narodowe" zwłaszcza jako nazwa kierunku studiów jest efektem braku znajomości wiedzy historycznej i socjologicznej, zastapionej kopiowaniem tradycyjnej siatki pojęciowej z wiedzy wojskowej albo o obronności (z epoki narodowej). Analiza kulturoznawcza potwierdziłaby powyższe ustalenia. W przypadku pojęć współczesnej nauki należy eliminować metafory, ponieważ uniemożliwiają one badanie rzeczywistości, narzucając niezgodne z nią wyobrażenia. Metafory, w przeciwieństwie do teorii naukowych, łatwo też zagnieżdżają się w umysłach ludzi i pozwalają, aby myśleniem kierowało uczucie.

Dlatego zamiast o „bezpieczeństwie narodowym” powinno się mówić o „bezpieczeństwie państwa”, czyli o bezpieczeństwie podstawowych politycznych jednostek terytorialnych, w jakie grupuje się gatunek ludzki. Jako potwierdzenie tej tezy można z powodzeniem przytoczyć ostatnio wydaną pracę Jana Rajchela i Eugeniusza Zabłockiego, pod tytułem 
Bezpieczeństwo narodowe. Pojęcie, kategorie, system. Autorzy bardzo się napracowali, zebrali ciekawe materiały z literatury przedmiotu, ale ich rozważania pomijają samodzielną analizę problematyki narodowej, analizę historyczna, socjologiczną i politologiczną. Zamiast tego wyczerpują swoje siły w referowaniu literatury, niesłusznie dzieląc bezpieczeństwo na międzynarodowe i narodowe. Wprawdzie próbują analizować relacje pomiędzy bezpieczeństwem państwa i bezpieczeństwem narodowym, ale $\mathrm{z}$ tej analizy nic nie wynika, natomiast po lekturze ich opisu bezpieczeństwa narodowego narzuca się wniosek, że to, co rozumieją jako bezpieczeństwo narodowe jest faktycznie bezpieczeństwem państwa (Rajchel, Zabłocki, 2016, s. 9-34). Nawet jeśli ustalili, że „Nie ma jednoznacznego i standardowego związku między narodem i państwem" (Rajchel, Zabłocki, 2016, s. 25), to i tak definiują bezpieczeństwo narodowe jako „[...] integralność terytorialną i suwerenność polityczną państwa [...]" (Rajchel, Zabłocki, 2016, s. 25). Trudno o większą niespójność we wnioskowaniu, ale wynika ona z zagubienia po lekturze wielu nonsensownych publikacji z zakresu bezpieczeństwa i teorii państwa. Gdyby autorzy lepiej poznali losy narodów, wówczas nie pokusiliby się o tak bardzo sprzeczne wnioski.

$\mathrm{Na}$ gruncie tych rozważań rodzi się zresztą inne pytanie. Czy bezpieczeństwo jako kierunek studiów uniwersyteckich nie powinno być „,bezprzymiotnikowe"? Czy nie powinno aspirować do takiego statusu, jaki mają prawo, czy politologia. Ustalenia socjologiczne pokazuja, że wprawdzie istnieje bezpieczeństwo sektorowe, wiele z tych sektorów dużo znaczy w życiu społecznym i powinno być przedmiotem specjalistycznych studiów, lecz dobrze wykształcony absolwent bezpieczeństwa, także bezpieczeństwa sektorowego, przede wszystkim powinien mieć wiedzę z zakresu bezpieczeństwa jako zjawiska społecznego. Inaczej takie studia będą tylko szkoleniem, typowym dla służb mundurowych. Może mają sens na uniwersytecie o statusie zakładu usługowego? To należałoby wyjaśnić.

W naszej opinii, studia przymiotnikowe mają sens jedynie na uczelniach, które uznają się za kontynuatorów jakiejś tradycji, na przykład narodowej, pożarniczej, wojskowej albo policyjnej. Studia uniwersyteckie powinny dostarczać wiedzy aktualnej, przede wszystkim podstawowej (aby na niej budować wiedzę specjalistyczna), a to oznacza, że bezpieczeństwo narodowe w ogóle nie ma sensu, zaś bezpieczeństwo wewnętrzne może być specjalizacją na studiach z zakresu bezpieczeństwa. Inna sprawa, że dzisiejszy pęd do tworzenia nowych kierunków studiów prowadzi do uznawania za kierunek studiów tego, co nadaje się najwyżej na specjalizację. 


\section{Wnioski}

$\mathrm{Na}$ gruncie argumentacji socjologicznej należy mówić wyłącznie o bezpieczeństwie jednostek i całości społecznych, natomiast w przypadku zbiorowości ludzkich kwestia bezpieczeństwa nie występuje, ponieważ one są zdolne dążyć jedynie do przetrwania. Pojęcie „,bezpieczeństwa narodu" jest wyłącznie metaforą. Faktycznie chodzi o bezpieczeństwo społeczeństwa zamieszkałego w państwie i intuicyjnie nazywanego narodem (także „narodem” kubańskim, szwajcarskim, nowozelandzkim, chińskim, amerykańskim, kanadyjskim czy australijskim).

Mamy więc tutaj do czynienia z bezpieczeństwem całości społecznej, jaką jest państwo, szukające swego ugruntowania w micie narodowym, pokazującym jego nieprzypadkowe pochodzenie. Często zresztą podmiotem jest społeczeństwo, które swojej tożsamości nie szuka w jakimkolwiek symbolu narodowym, ale odwołuje się do niejasnej tradycji i narracji narodowej, ponieważ taki jest zwyczaj światowy, narzucony przez wielkie potęgi.

Problematyka bezpieczeństwa określanego jako „,narodowe” jest częścią mitu narodowego, silnie związanego z ideą obronności, faktycznie zaś obronności określanej mianem „narodowej”. Nauka określana jako „bezpieczeństwo narodowe” dysponuje nazwą o charakterze metafory6. Należałoby ją zastąpić pojęciem „bezpieczeństwo państwa”, ale przyzwyczajenia jak na razie nie dopuszczają do tego. Bezpieczeństwo państwa jest zjawiskiem, które może być badane naukowo, po oczyszczeniu pytań badawczych ze słownictwa i idei narodowych. Bezpieczeństwo państwa nie jest zjawiskiem narodowym, tylko społecznym, a więc jest to fenomen socjologiczny, politologiczny, prawny czy ekonomiczny. Być może jest to fenomen kwalifikujący się do wyłonienia nowej dyscypliny nauki.

Jak bardzo problematyka narodowa ma charakter pseudonaukowy, pokazują problemy związane $\mathrm{z}$ funkcjonowaniem współczesnych wielkich potęg. Państwa narodowe, a więc państwa, w których dominuje jakiś naród, nigdy nie tworzyły większości. Także dzisiaj na świecie są mniejszością. Ich uprzywilejowaną pozycję określa właściwa im potęga gospodarcza i militarna. Dzięki niej narzucają swoją władzę, własne mity

6 Jak „stosunki międzynarodowe”. Uwikłanie w metaforę powoduje, że nauka o stosunkach międzynarodowych nie jest dzisiaj dyscypliną nauki, pomimo długiej historii i literatury przedmiotu, jakiej bezpieczeństwo nie dopracuje się z pewnością w najbliższych dziesięcioleciach. 
i wizje. Często także to, co określa się mianem nauki, a co zwykle jest pseudonauką, dokładniej zaś doktryną7.

\section{Bibliografia}

Anderson B. (1997), Wspólnoty wyobrażone: rozważania o źródlach i rozprzestrzenianiu się nacjonalizmu, Wydawnictwo Znak, Kraków.

Bezpieczeństwo w perspektywie socjologicznej (2001), red. A. Kołodziejczyk, Wojskowe Biuro Badań Socjologicznych, Warszawa.

Clausewitz C. (1995), O wojnie, Wydawnictwo Test, Lublin.

Creveld M. (1999), The Rise and Decline of the State, Cambridge University Press, Cambridge.

Hobbes T. (1954), Lewiatan, Państwowe Wydawnictwo Naukowe, Warszawa.

Kant I. (1995), O wiecznym pokoju. Zarys filozoficzny, thum. F. Przybylak, Wydawnictwo Uniwersytetu Wrocławskiego, Wrocław.

Kennedy P. (1994), Mocarstwa świata. Narodziny - rozkwit-upadek. Przemiany gospodarcze i konflikty zbrojne w latach 1500-2000, Książka i Wiedza, Warszawa.

Kołodziejczyk A. (2001), Od socjologii wojska do socjologii bezpieczeństwa narodowego?, w: Bezpieczeństwo w perspektywie socjologicznej, red. A. Kołodziejczyk, Wojskowe Biuro Badań Socjologicznych, Warszawa.

Kołodziejczyk A. (red.) (2001), Bezpieczeństwo w perspektywie socjologicznej, Wojskowe Biuro Badań Socjologicznych, Warszawa.

Krauthammer C. (1990/91), The Unipolar Moment, „Foreign Affairs”, vol. 70, nr 1.

Maciejewski J. (red.) (2001), Socjologiczne aspekty bezpieczeństwa, Wydawnictwo Uniwersytetu Wrocławskiego, Wrocław.

Mączak A. (1986), Rządzacy i rzq̨dzeni, Państwowy Instytut Wydawniczy, Warszawa.

Ossowski S. (1983), O osobliwościach nauk spolecznych, Państwowe Wydawnictwo Naukowe, Warszawa.

Peebles P. (2006), The History of Sri Lanka, Greenwood Publishing Group, Westport-Connecticut-London.

Pawłowski J. (red.) (2015), Podstawy bezpieczeństwa wspótczesnego państwa (podmiotu). Implikacje, Wydawnictwo Akademii Obrony Narodowej, Warszawa.

Poleszczuk J. (2014), Socjologia - projekt epistemologicznie otwarty, w: Przedmiot poznania w politologii, red. R. Skarzyński, Wydawnictwo Temida 2, Białystok.

Rajchel J., Zabłocki E. (2016), Bezpieczeństwo narodowe. Pojęcie, kategorie, system, Wydawnictwo Wyższej Szkoły Oficerskiej Sił Powietrznych, Dęblin.

Reinhard W. (2000), Geschichte des Staatsgewalt. Eine vergleichende Verfassungsgeschichte Europas von den Anfängen bis zur Gegenwart, C.H. Beck Verlag, München.

${ }^{7}$ Np. doktryną świata jednobiegunowego, jak ją ogłosił Charles Krauthammer (Krauthammer, 1990/91). 
Schulze H. (2012), Państwo i naród w dziejach Europy, Wydawnictwo Uniwersytetu Warszawskiego, Warszawa.

Skarzyński R. (2006), Anarchia i policentryzm. Elementy teorii stosunków międzynarodowych, Wydawnictwo Wyższej Szkoły Ekonomicznej, Białystok.

Skarzyński R. (2011), Mobilizacja polityczna. Wspólpraca i rywalizacja człowieka współczesnego w wielkiej przestrzeni i długim czasie, Dom Wydawniczy Elipsa, Warszawa.

Socjologiczne aspekty bezpieczeństwa narodowego (2001), red. J. Maciejewski, Wydawnictwo Uniwersytetu Wrocławskiego, Wrocław.

Spruyt H. (1994), The Sovereign State and its Competitors. An Analysis of Systems Change, Princeton University Press, Princeton.

Sztompka P. (2002), Socjologia. Analiza społeczeństwa, Wydawnictwo Znak, Kraków.

Turner J. (2004), Struktura teorii socjologicznej, Wydawnictwo Naukowe PWN, Warszawa.

Weber M. (2002), Gospodarka i społeczeństwo. Zarys socjologii rozumiejacej, Wydawnictwo Naukowe PWN, Warszawa.

Zalewski S. (2013), Bezpieczeństwo polityczne. Zarys problematyki, Wydawnictwo Uniwersytetu Przyrodniczo-Humanistycznego, Siedlce.

\section{Security as a social phenomenon}

\section{Summary}

Security has rightly been included in the social sciences in Poland. Carl von Clausewitz stated that war is a continuation of politics using other means. According to Clausewitz, war is "an act of relations between people," and by this token it is a phenomenon of social life. Clausewitz not only explained the phenomena of struggle and war, but also their origins through the prism of society and security - not as a threat but as a response to threats. The purpose of the paper is to show security as a social phenomenon by distinguishing the differences between security and survival. In fact, Hobbes argued that it is not possible to provide security for a society operating as a community (i.e. outside the state) because its existence is not protected by anybody. This means that such social entities are concerned only with survival in the context of the internal competition of small groups whose proportions of force change easily and quickly. The issue of security becomes even more significant when it comes to the possibility of such an entity disintegrating, whether from the inside (e.g. betrayal) or by outsiders when they penetrate the relationship (immigration) or try to destroy it in a rivalry (aggression).

Key words: security, Clausewitz, society, conflict 
